\title{
PENGARUH MEDIA TANAM TERHADAP PERTUMBUHAN BIBIT KAYU PUTIH (Melaleuca cajuputi)
}

\author{
Mia Rahmania ${ }^{\text {a) }}$, Hafizah Nahlunnisa ${ }^{\text {b) }}$ \\ a) Mahasiswa Prodi Kehutanan, Fakultas Sains Teknik, dan Terapan, Undikma Mataram \\ b) Dosen Prodi Kehutanan, Fakultas Sains Teknik, dan Terapan, Undikma Mataram \\ *email mia
}

\begin{abstract}
Abstrak
Kayu putih (Melaleuca cajuputi) merupakan jenis dari famili Myrtaceae yang mengandung minyak atsiri berpotensi mendukung industry minyak atsiri dan juga digunakan untuk kegiatan rehabilitasi lahan. Tujuan dari penelitian ini untuk mengetahui pengaruh media tanam terhadap pertumbuhan bibit tanaman kayu putih. Metode yang digunakan dalam penelitian ini yaitu metode eksperimental menggunakan rancangan acak lengkap (RAL) yang terdiri dari 1 faktor perlakuan yaitu media tanam (M) yang terdiri dari 5 aras (tanah, tanah:pasir (2:1), tanah:pasir (1:2), Tanah : Pasir Zeolit Mikoriza (1/10\%), dan tanah:kompos (1:1) ) dengan masing-masing tiga pengulangan. Parameter pertumbuhan yang diamati yaitu tinggi tanaman, jumlah daun, diameter batang, dan panjang akar. Analisis data menggunakan uji anova pada taraf uji 0,05 . Jika terdapat perbedaan yang nyata, maka dilakukan uji lanjutan BNJ. Hasil yang diperoleh dari penelitian ini yaitu media tanam memberikan pengaruh nyata kepada parameter pertumbuhan jumlah daun, sedangkan pertumbuhan tinggi tanaman, diameter batang dan panjang akar tidak memberikan pengaruh yang nyata terhadap parameter perlakuan. Media tanam M3 (tanah + pasir Zeolit Mikoriza 1/10\%) memberikan pengaruh lebih baik dibandingkan dengan media lainnya pada parameter tinggi tanaman dan jumlah daun. Hasil uji Anova menyatakan media tanam tidak berpengaruh signifikan terhadap tinggi tanaman dan panjang akar. Sedangkan pada jumlah daun memberikan hasil berpengaruh signifikan pada minggu keenam.
\end{abstract}

Keywods : Kayu putih, media tanam, pertumbuhan

\section{PENDAHULUAN}

Salah satu sumber pendapatan negara berasal dari hasil hutan bukan kayu. Kayu putih merupakan salah satu tanaman penghasil produk hasil hutan bukan kayu yang perlu dikembangkan karena memiliki prospek yang cukup baik. Kayu putih (Melaleuca cajuputi) merupakan salah satu tanaman penghasil minyak atsiri yang digunakan dalam industry minyak atsiri skala besar maupun rumah tangga. Tanaman ini kaya akan minyak atsiri yang sangat penting untuk farmakologi atau obatobatan karena mengandung senyawa pokok berupa 1,8 cineol yang tinggi (Doran et al., 1997 dalam Kartikawati et al., 2014).

Saat ini kebutuhan minyak kayu putih meningkat dari tahun ke tahun, sehingga produksi minyak kayu putih tidak dapat memenuhi kebutuhsn tersebut. Kartikawati \& Rimbawanto (2014) menyatakan bahwa kebutuhan minyak kayu putih dalam negeri mencapai 1.500 ton/tahun, sedangkan produksi tahunan hanya berkisar 400 ton/tahun. Sehingga untuk memenuhi kebutuhan tersebut, indutri farmasi mengimpor produk komplementer berupa minyak eucalyptus dari Cina.

Selain penghasil minyak atsiri, tanaman kayu putih juga berpotensi untuk upaya rehabilitasi lahan, seperti menunjang usaha konservasi lahan dan pemanfaatan lahan marginal menjadi lahan produktif. Hal ini dikarenakan tanaman kayu putih termasuk kedalam jenis tanaman intoleran, yaitu tanaman yang sangat membutuhkan cahaya matahari dan tidak tahan terhadap naungan. Rimbawanto et al. (2014) menyatakan bahwa tanaman kayu putih dapat tumbuh dengan baik di lahan yang kurang subur atau tandus. Selain itu penelitian Mawaddah (2012) menyatakan bahwa kayu putih dapat tumbuh dengan baik pada kondisi genangan air asam tambang.

Pertumbuhan tanaman dipengaruhi oleh beberapa faktor yaitu eksternal dan internal. Faktor internal merupakan faktor yang terdapat pada kualitas benih tanaman itu sendiri. Sedangkan faktor eksternal merupakan faktor lingkungan salah satunya adalah media tanam. Media tanam yang baik umumnya menyediakan 
air dan unsure hara dalam jumlah cukup bagi pertumbuhan tanaman (Gardner dan Mitchell, 1991). Prayugo (2007) menyebutkan bahwa media tanam yang baik harus memiliki persyaratan-persyaratan sebagai tempat berpijak tanaman, memiliki kemampuan mengikat air dan menyuplai unsur hara yang dibutuhkan tanaman, mampu mengontrol kelebihan air (drainase) serta memiliki sirkulasi dan ketersediaan udara (aerasi) yang baik, dapat mempertahankan kelembaban di sekitar akar tanaman dan tidak mudah lapuk atau rapuh. Pentingnya media tanam dalam pertumbuhan kayu putih merupakan usaha awal dalam kegiatan budidaya kayu putih.

Berdasarkan uraian diatas, terdapat peluang yang besar dalam pengembangan budidaya tanaman kayu putih. Sehingga untuk memperkaya informasi mengenai budidaya tanaman kayu putih, maka penting untuk dilakukan penelitian tentang budidaya tanaman kayu putih dengan berbagai media tanam. Penelitian ini bertujuan untuk mengetahui pengaruh media tanam terhadap pertumbuhan kayu putih (Melaleuca cajuputi).

\section{METODOLOGI PENELITIAN}

Metode yang digunakan dalam penelitian ini adalah metode eksperimental. Metode eksperimental merupakan metode penelitian yang digunakan untuk mencari pengaruh perlakuan tertentu terhadap yang lain dalam kondisi yang terkendali (Sugiyono, 2011).

\section{a. Alat dan Bahan}

Alat-alat yang digunakan dalam penelitian ini adalah alat tulis, kamera, penggaris, ayakan berukuran $5 \mathrm{~mm}$, caliper. Bahan yang digunakan dalam penelitian ini adalah bibit kayu putih, air, polibag, pasir, tanah, kompos, Paranet.

\section{b. Rancangan Percobaan}

Rancangan yang digunakan dalam penelitian ini adalah Rancangan Acak Lengkap (RAL), dan dilakukan dengan lima kali ulangan. Faktor penggunaan media tanam terdiri dari 4 aras yaitu :

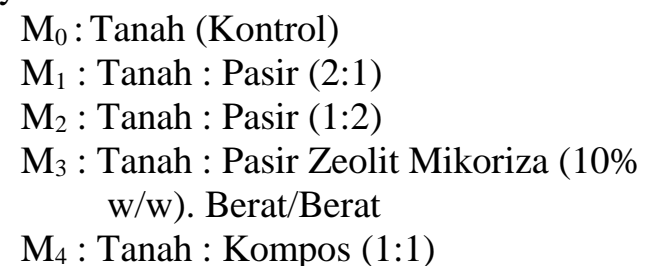

Dari media tanam tersebut diperoleh 5 perlakuan. Masing masing perlakuan di ulang sebanyak 3 kali. Pada masing masing ulangan terdapat 3 tanaman, sehingga total keseluruhan diperoleh 5 × $3=15$ tanaman percobaan.

Tabel 1. Kombinasi perlakuan penggunaan media tanam

\begin{tabular}{|l|l|l|}
\hline \multicolumn{3}{|c|}{ Blok } \\
\hline 1 & 2 & 3 \\
\hline $\mathrm{M}_{0}$ & $\mathrm{M}_{1}$ & $\mathrm{M}_{2}$ \\
\hline $\mathrm{M}_{1}$ & $\mathrm{M}_{3}$ & $\mathrm{M}_{0}$ \\
\hline $\mathrm{M}_{2}$ & $\mathrm{M}_{4}$ & $\mathrm{M}_{4}$ \\
\hline $\mathrm{M}_{3}$ & $\mathrm{M}_{0}$ & $\mathrm{M}_{1}$ \\
\hline $\mathrm{M}_{4}$ & $\mathrm{M}_{2}$ & $\mathrm{M}_{3}$ \\
\hline
\end{tabular}

\section{c. Cara Kerja}

\section{Persiapan}

a. Bibit Kayu putih

Bibit kayu putih yang digunakan diperoleh dari Dusun Bentek Kecamatan Gangga Kabupaten Lombok Utara.

b. Media Tanam

1. Tanah yang digunakan terlebih dahulu dikering anginkan dan dibersihkan dari gulma. Selanjutnya tanah diayak menggunakan ayakan berukuran $5 \mathrm{~mm}$.

2. Pasir diayak menggunakan ayakan berukuran $5 \mathrm{~mm}$. Pasir dan tanah dicampurkan dengan perbandingan 2 : $1,1: 2$

3. Kompos dikering anginkan, selanjutnya diayak menggunakan ayakan berukuran $5 \mathrm{~mm}$. Kompos dan tanah dicampurkan dengan perbandingan 1:1.

4. Pasir Zeolit terinduksi mikoriza berupa spora dicampur dengan media tanah menurut perbandingan $10 \%$ w/w.

c. Persiapan Polibag

Ukuran polibag yang digunakan yaitu $5 \times 10 \mathrm{~cm}$. Selanjutnya polibag diisi dengan media tanam berupa tanah + pasir, tanah + pasir Zeolit mikoriza, tanah + kompos, masing masing sebanyak 3 kali ulangan. 


\section{Pelaksanaan}

a. Pemindahan bibit ke polibag

1. Setelah Bibit berusia 20 hari, bibit dipindahkan ke polibag yang telah terisi media tanam sesuai dengan rancangan percobaan.

2. Setelah bibit ditanam, kemudian bibit disiram agar tetap segar.

b. Penyiraman

Penyiraman dilakukan setiap pagi dan sore agar tanaman dapat tumbuh dengan baik.

c. Pemeliharaan

Salah satu faktor penghambat pertumbuhan tanaman yaitu munculnya gulma. Untuk itu dilakukan dengan cara penyiangan. Selain itu dilakukan pemeliharaan untuk pengendalian hama dan penyakit.

\section{Parameter Pengamatan Penelitian}

Pengamatan terhadap pertumbuhan semai dilakukan tiap 1 minggu meliputi pengambilan data pada parameter yang diamati yakni sebagai berikut :

a. Tinggi Batang $(\mathrm{cm})$

Pengukuran panjang batang diukur menggunakan penggaris. Pengukuran dilakukan tiap 1 minggu. Pastikan parameter awal pertumbuhan sudah diukur terlebih dahulu.

b. Jumlah Daun

Jumlah daun dihitung setiap minggu.

c. Panjang Akar

Kegiatan Pengukuran akar dilakukan pada saat pemanenan terakhir.

\section{d. Analsis Data}

Semua data parameter pengamatan dianalisis tingkat signifikasinya dengan program Exell. Jika terdapat perbedaan signifikan, dilanjutkan dengan uji Beda Nyata Jujur (BNJ) pada taraf 0,05. Uji ANOVA dan BNJ dianalisis dengan Microsoft Office Exell.

\section{HASIL dan PEMBAHASAN a. Tinggi Batang}

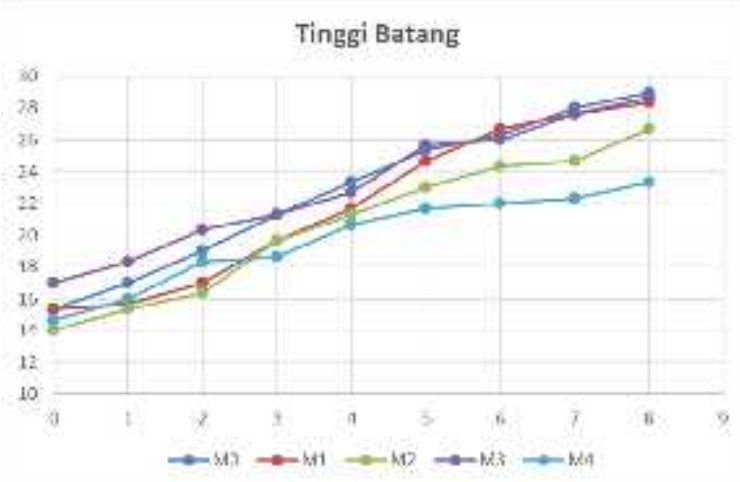

Gambar 1. Rata-rata pertumbuhan tinggi batang pada setiap media tanam

Hasil pengamatan terhadap tinggi batang diperoleh penambahan tinggi dari minggu pertama sampai minggu ke delapan. Pertumbuhan tinggi tanaman terjadi pada semua media tanam, dan pertambahan tinggi tanaman yang paling besar yaitu pada media tanah + pasir Zeolit mikoriza 1 : $10 \%\left(\mathrm{M}_{3}\right)$ pada minggu pertama hingga minggu ketiga. Sedangkan pada minggu keempat hingga kedelapan, pertambahan tinggi tanaman yang paling besar berturut-turut terdapat pada media tanah (M0), tanah+ pasir Zeolit mikoriza $1: 10 \%\left(\mathrm{M}_{3}\right)$, tanah + Pasir 2:1 (M 1 ), tanah (M0) dan tanah (M0).

Gambar 1 menunjukkan bahwa rata-rata tinggi tanaman yang paling besar adalah $29 \mathrm{~cm}$ pada media tanah (M0), namun tidak berbeda signifikan dengan media lain yaitu pada media tanah + pasir zeolit mikoriza $1: 10 \%\left(\mathrm{M}_{3}\right)$, tanah + pasir 2: $1\left(\mathrm{M}_{1}\right)$, tanah + pasir $1: 2\left(\mathrm{M}_{2}\right)$, tanah + kompos $1: 1\left(\mathrm{M}_{4}\right)$, yang menunjukkan rata-rata pertumbuhan tinggi tanaman berturut turut sebesar $28,66 \mathrm{~cm}, 28,33 \mathrm{~cm}, 26,66 \mathrm{~cm}$, dan $23,33 \mathrm{~cm}$. Hasil uji lanjut Anova pada taraf 0,05 diperoleh bahwa media tanam tidak berpengaruh signifikan terhadap tinggi tanaman pada minggu pertama hingga minggu ke delapan. Hasil yang diperoleh berbeda dengan penelitian Afifah (2016) yang menunjukkan bahwa media tanam berpengaruh signifikan terhadap tinggi tanaman kayu putih. Hal ini dikarenakan media tanam yang digunakan pada penelitian tersebut berbeda jenisnya dengan media pada penelitian ini.

Pertumbuhan tinggi batang kayu putih pada media tanam yang tanah+pasir memiliki nilai yang cukup tinggi, dibandingkan dengan media tanah+kompos. Menurut Wedhana (2018) salah satu faktor yang berpengaruh nyata terhadap pertumbuhan tinggi batang kayu putih 
adalah fraksi pasir, bulk density, dan kedalaman efektif.

Media tanam dengan menggunakan tanah + pasir zeolit mikoriza $1: 10 \%\left(\mathrm{M}_{3}\right)$ menunjukkan tingkat pertambahan tinggi yang lebih banyak di setiap minggu dibandingkan dengan media lainnya. Hal ini sebagaimana dijelaskan oleh Sumarlin et al. (2008) yang menyatakan bahwa media tanam zeolit dapat berfungsi sebagai absorben ion atau molekul yang ada di sekitarnya. Media zeolit dapat menyerap unsur hara dengan mengeluarkannya sesuai kebutuhan tanaman. Walaupun perbedaan tersebut tidak signifikan dibandingkan dengan media lainnya, dan juga tidak memberikan pengaruh yang signifikan terhadap pertumbuhan tinggi tanaman, karena rata-rata yang diperoleh hamper sama dengan media lain. Namun pada media tanah+ pasir zeolit mikoriza $1: 10 \%\left(\mathrm{M}_{3}\right)$ memiliki pertumbuhan tinggi tanaman paling besar selama 5 minggu. Menurut Ani dkk (1997) zeolit sebagai mineral alami yang berbentuk kristal dan memiliki rongga yang terisi ion logam serta molekul air dapat meningkatkan terjadinya proses pertukaran ion logam yang diperlukan oleh tanaman dengan baik.

Hasil penelitian Karti (2006) tentang penggunaan zeolit, pasir, dan tanah sebagai media tumbuh menunjukkan bahwa hasil terbaik yaitu menggunakan media tumbuh dengan zeolit dan tanaman inang $S$ bicolor, yang kemudian diikuti dengan media tumbuh pasir dan tanah. Sedangkan mikoriza adalah simbiosis antara fungi tanah dengan akar tanaman yang memiliki banyak manfaat di bidang pertanian, diantaranya adalah membantu meningkatkan status hara tanaman, meningkatkan ketahanan tanaman terhadap kekeringan, penyakit, dan kondisi tidak menguntungkan lainnya (Auge 2001). Nurbaity (2009) menyatakan secara visual tanaman yang ditumbuhkan pada media zeolit yang dikombinasikan dengan mikoriza menunjukkan pertumbuhan yang lebih baik dengan media lainnya. Berdasarkan hal tersebut, dapat menjadi dasar alasan media pasir zeolit mikoriza memberikan hasil terbaik dibandingkan dengan media lainnya.

\section{b. Jumlah Daun}

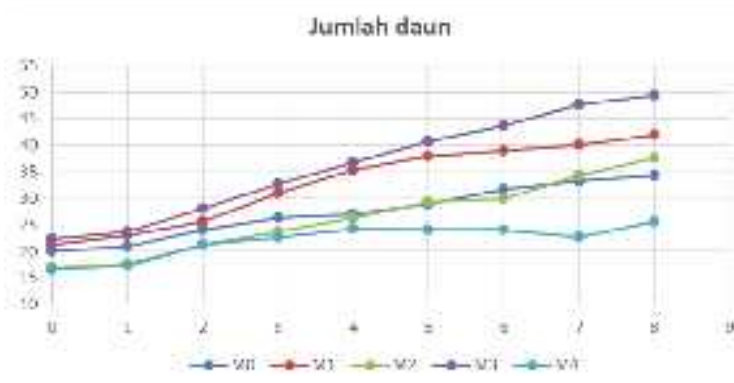

Gambar 2. Rata-rata pertumbuhan jumlah daun pada setiap media tanam

Gambar 2 menunjukkan pertumbuhan jumlah daun yang paling tinggi yaitu terdapat pada media tanah + pasir zeolit mikoriza 1 : $10 \% \mathrm{w} / \mathrm{w}\left(\mathrm{M}_{3}\right)$ dari minggu pertama hingga minggu kedelapan. Rata-rata jumlah daun yang dimiliki oleh tanaman kayu putih pada media tersebut yaitu 49,33 helai. Selanjutnya rata-rata jumlah daun pada media $\mathrm{M}_{1}$ sebesar 42 helai, media $\mathrm{M}_{2}$ dengan rata rata 38 helai, media $\mathrm{M}_{0}$ dengan nilai rata rata 34 helai, dan media $\mathrm{M}_{4}$ dengan rata-rata 25 helai.

Hasil uji lanjut Anova pada taraf 0,05 di minggu pertama hingga minggu kelima, juga minggu ketujuh dan kedelapan menunjukkan bahwa media tanam tidak berpengaruh signifikan terhadap jumlah daun. Sedangkan pada minggu keenam, hasil uji lanjut Anova pada taraf 0,05 menunjukkan media tanam berpengaruh signifikan terhadap jumlah daun. Pada minggu keenam, hasil pengamatan menunjukan jumlah daun yang paling tinggi yaitu pada media Tanah + Pasir Zeolit Mikoriza 1 : $10 \%$ w/w $\left(\mathrm{M}_{3}\right)$ dengan rata-rata 44 helai, diikuti oleh media $M_{1}$ dengan nilai rata-rata sebesar 39 helai, media $\mathrm{M}_{0}$ dengan rata rata 32 helai, media $\mathrm{M}_{2}$ dengan nilai rata rata 30 helai dan media $\mathrm{M}_{4}$ dengan rata-rata 24 helai. Hasil uji lanjut anova pada minggu keenam menunjukan $\mathrm{F}$-value sebesar $0,03>\alpha 0,05$ atau $\mathrm{F}$ hitung < F tabel.maka akan di uji lanjut Beda Nyata Jujur (BNJ).

Tabel 2. Hasil analisis uji BNJ

$\begin{array}{cccc}\text { BNJ } & & & \\ \text { Urutan } & \text { Perlakuan } & \text { Rerata } & \text { Notasi } \\ 1 & \mathrm{M}_{4} & 24 & \mathrm{~A} \\ 2 & \mathrm{M}_{2} & 30 & \mathrm{Ab} \\ 3 & \mathrm{M}_{0} & 31,6 & \mathrm{Ab} \\ 4 & \mathrm{M}_{1} & 39 & \mathrm{Ab} \\ 5 & \mathrm{M}_{3} & 43,6 & \mathrm{~B}\end{array}$


Hasil analisis uji BNJ minggu keenam menunjukan bahwa media tanam berpengaruh signifikan atau berbeda nyata terhadap jumlah daun. Media $\mathrm{M}_{4}$ berbeda nyata terhadap $\mathrm{M}_{3}$, akan tetapi $\mathrm{M}_{2}$ tidak berbeda nyata terhadap $\mathrm{M}_{0}$ dan $\mathbf{M}_{1}$ artinya tidak ada perbedaan antara $\mathbf{M}_{2}$, $\mathbf{M}_{0}$, dan $\mathbf{M}_{1}$. Hal ini sesuai dengan penelitian Afifah (2016) yang menunjukkan bahwa media tanam berpengaruh signifikan terhadap jumlah daun kayu putih. Perbedaan ini dikarenakan jumlah daun pada media M4 memiliki selisih yang cukup jauh dengan media M3. Media tanah + kompos 1:1( $\left(\mathrm{M}_{4}\right)$ memiliki jumlah daun 24 helai sedangkan media tanah + pasir zeolit mikoriza 1 : $10 \% \mathrm{w} / \mathrm{w}\left(\mathrm{M}_{3}\right)$ memiliki jumlah daun 44 helai. Media tanah+kompos 1:1 (M4) menunjukkan hasil yang paling rendah dalam pertumbuhan jumlah daun. Menurut Rahmawati (2020) perlakuan media tanah dan kompos daun kiara payung pada bibit kayu putih dapat menghambat pertumbuhan tanaman. HagenThorne et al. (2006) juga menyatakan bahwa serasah daun yang tua kemudian gugur, miskin akan unsur hara. Karena telah dipindahkan kebagian tanaman yang lain dan telah mengalami pencucian. Hal ini dapat menjadi penyebab rendahnya pertumbuhan jumlah daun pada media tanah+kompos.

Hasil pengamatan pada minggu ketujuh hingga kedelapan menunjukkan bahwa jumlah daun terbanyak terletak pada media tanam Tanah + Pasir Zeolit Mikoriza 1: 10\% (M3) dengan rata-rata 47,66 helai dan 49,33 helai di minggu ke delapan. Selanjutnya diikuti oleh media $\mathrm{M}_{1}$ dengan nilai rata-rata sebesar 42 helai, media $\mathrm{M}_{2}$ dengan rata rata 37,66 helai (37 helai), media $\mathrm{M}_{0}$ dengan nilai rata rata 34,33 helai (34 helai), dan media $M_{4}$ dengan rata-rata 25,66 helai (25 helai). Setelah dilakukan uji lanjut Anova pada taraf 0,05 media tanam tidak berpengaruh signifikan terhadap jumlah daun pada minggu ketujuh dan kedelapan, karena hasil uji anova menunjukan F-value sebesar $0,13>\alpha 0,05$ atau $\mathrm{F}$ hitung $<\mathrm{F}$ tabel.

Harjadi (1996) menyatakan bahwa jumlah daun berkaitan dengan tinggi tanaman, dimana semakin tinggi tanaman maka semakin banyak daun yang terbentuk, karena daun keluar dari nodusnodus yakni tempat kedudukan daun yang ada pada batang. Hal ini sesuai dengan hasil pengamatan bahwa tanaman yang memiliki tinggi terbesar dan jumlah daun terbanyak, sama-sama terletak pada media tanam Tanah + Pasir Zeolit Mikoriza 1: 10\% (M3).

\section{c. Panjang Akar}

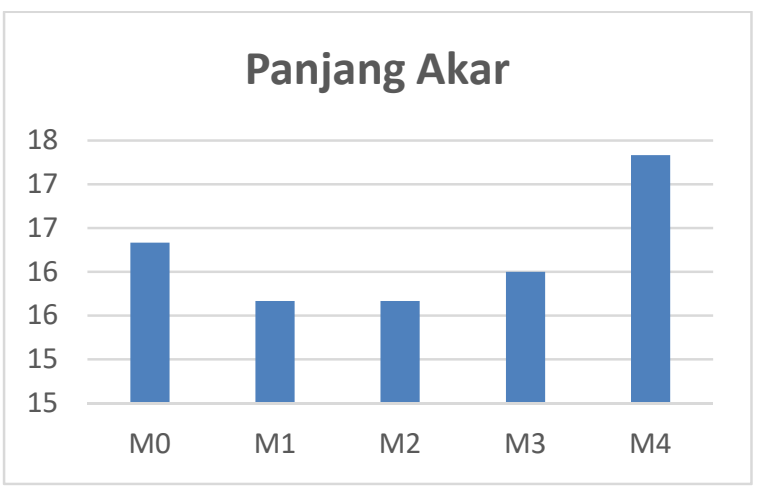

Gambar 3. Rata-rata panjang akar pada setiap media tanam

Hasil pengamatan panjang akar kayu putih pada minggu kedelapan yaitu akar terpanjang terdapat pada media tanah+kompos 1:1 (M4) dengan rata-rata $17,33 \mathrm{~cm}$. Selanjutnya media tanah (M0) memiliki nilai rata-rata 16,33 $\mathrm{cm}(16 \mathrm{~cm})$, media $\mathrm{M}_{3}$ dengan rata rata $16 \mathrm{~cm}$, media $\mathrm{M}_{1}$ dengan nilai rata rata $15,66 \mathrm{~cm}$, dan media $\mathrm{M}_{2}$ dengan rata-rata $15,66 \mathrm{~cm}$. Hasil analisis uji lanjut Anova pada taraf 0,05 media tanam tidak berpengaruh signifikan terhadap panjang akar pada minggu kedelapan, karena hasil uji anova pada data tersebut menunjukan F-value sebesar $0,94>\alpha 0,05$ atau $\mathrm{F}$ hitung $<\mathrm{F}$ tabel.

Hardjowigeno (2011) menyatakan bahwa pertumbuhan akar dipengaruhi oleh kondisi kedalaman tanah, tanah dengan kedalaaman dangkal akan menghambat perkembangan akar tanaman, sedangkan tanah yang mempunyai aerasi dan drainase yang baik, akan mampu menyokong perkembangan akar dengan baik pula. Sehingga perkembangan akar termasuk panjang akar tidak dipengaruhi oleh jenis tanah atau media tanamnya, melainkan dipengaruhi oleh kondisi kedalaman efektif tanah.

\section{KESIMPULAN}

Media tanam tidak memberikan pengaruh nyata terhadap parameter tinggi tanaman dan panjang akar. Sedangkan pada parameter jumlah daun, media tanam memberikan pengaruh signifikan pada minggu ke enam. Media tanam M3 (tanah + pasir Zeolit Mikoriza 1/10\%) memberikan 
pengaruh pada pertumbuhan bibit tanaman Kayu Putih (Melaleuca cajuputi) yang lebih baik dibandingkan dengan media M0 (tanah control), M1 (tanah + pasir 2: 1), M2 (tanah + pasir 1: 2) dan M4 (tanah + kompos $1: 1$ ) dengan parameter tinggi tanaman dan jumlah daun.

\section{SARAN}

Perlu dilakukan penelitian lebih lanjut dengan parameter faktor cahaya misalnya di dalam paranet dan diruang terbuka.

\section{DAFTAR PUSTAKA}

Afifah H, Raden Sutrino, Irwan Mahakam Lesmono Aji. Pengaruh Media Tanam dan Frekuensi Penyiraman terhadap Pertumbuhan Semai Tanaman Kayu Putih (Melaleuca cajuputi). GaneCSwara. 10(1) :107-114(2016)

Auge, R.M. 2001. Water Relations, Drought And Vesicular - Arbuscular Mycorrhizal Symbiosis. Mycorrhiza : 3-42.

Ani S., C. Bambang dan R. Sugianto. 1997. Pemanfaatan zeolit sebagai campuran pupuk anorganik dalam upaya meningkatkan produktivitas tanaman tebu. Prosiding Konferensi Energi Sumber Daya Alam dan Lingkungan (ESDAL). Bidang Sumberdaya Alam 1 ; 173-180.

Garner, P. F,R. B Preace dan R.L. Mitchell. 1991. Physiology of Crop Plant, terjemahan Fisiologi Tanaman Budidaya. Universitas Indonesia. Jakarta. 428 hal.

Hagen-Thorne, A., Varnagiryte, I., Nihlgard, B., \& Armolaitis, K.. Autumn nutrient resorption and losses in four deciduous forest tree species. For. Ecol. Manage. 228:33-39(2006).

Handayani S. 2011. Pengaruh pupuk daun terhadap pertumbuhan beberapa pohon kehutanan pada kondisi tergenang.skripsi. Fakultas Kehutanan IPB. Bogor

Hardjowigeno, S. 2011. Evaluasi Kesesuaian Lahan dan Perencanaan Tataguna Lahan. Gadjah Mada University Press. Yogyakarta.

Harjadi, M.M.S.S.1996. Pengantar Agronomi. Gramedia Pustaka Utama. Jakarta.
Kartikawati, N.K. dan Rimbawanto, A. 2014. Potensi Pengembangan Industri Minyak Kayu Putih . Pusat Penelitian dan Pengembagan Hutan Tanaman. Departemen Kehutanan.

Karti, Setiana, M.A., Ariyanti, dan G.J., Kusumawati R. Penggunaan Zeolit, Pasir dan Tanah sebagai Media Tumbuh danRumput serta Legum Pakan Sebagai Tanaman Inang untuk Produksi Massal Inokulum Cendawan Mikoriza arbuskula. Jurnal Zeolit Indonesia. 5(1): 33-37 (2006)

Kartikawati, N.K. dan Rimbawanto, A. 2014. Potensi Pengembangan Industri Minyak Kayu Putih. Pusat Penelitian dan Pengembangan Hutan Tanaman. Departemen Kehutanan.

Kartikawati, N.K., Rimbawanto, A., Susanto, M., Baskorowati, L., dan Prastyono. 2014. Budidaya dan Prospek Pengembangan Kayu Putih (Melaleuca cajuputi). : IPB Press. Jakarta

Mawaddah M, Irdika M, Lana S. 2012. Pertumbuhan Kayu Putih (Melaleuca leucadendron Linn.) dan Longkida (Nauclea orientalis Linn.) pada Kondisi Tergenang Air Asam Tambang. Jurnal Silvikultur Tropika. 3(2): 71-75 (2012).

Nurbaity A, Herdiyantoro D, Mulyani O. Pemanfaatan Bahan Organik sebagai Bahan Pembawa Inokulan Fungi Mikoriza Arbuskula Jurnal Biologi. 9(1): 7-11 (2009)

Prayugo, S. 2007. Media Tanam untuk Tanaman Hias. Penebar Swadaya. Jakarta.

Rahmawati NR, Emmy Winarni, dan Damaris Payung. Pertumbuhan Bibit Kayu Putih (Melaleuca cajuputi) pada Berbagai Kombinasi Kompos Seresah Daun Kiara Payung (Filicium sp) dan Pupuk Kandang sebagai Media Sapih. Jurnal Sylva Scienteae.3(2):385-393(2020)

Rimbawanto, A., Susanto, M., Khosmah, M.K., Adinugraha, H.A., dan Utomo, P.M, 2014. Buku Seri Iptek V Kehutanan Topik 1 Kayu putih. Badan Penelitian dan Pengembangan Kehutanan. Kementerian Kehutanan Republik Indonesia.

Sugiono. 2011. Metode Penelitian Kuantitatif Kualitatif dan $R \& D$. Alfabeta. Bandung. 
Sumarlin, L. O., Muharam, S., dan Vitaria, A. (2008) Pemerangkapan ammonium(NH4+) dari urin dengan Zeolit pada berbagai variansi konsentrasi urin. Jurnal Kimia. Vol. 1:110-117.

Wedhana IB, Muhammad Husni Idris, Rato Firdaus Silamon. Analisis Pertumbuhan Tanaman Kayu Putih (Melaleuca cajuputi sub sp. cajuputi) Pada Kawasan Hutan Lindung Dusun Malimbu dan Dusun Badung Resort Malimbu KPHL Rinjani Barat. Jurnal Belantara. 1(1): 35-44. (2018) 